\title{
Helminths from the red-eared slider Trachemys scripta elegans (Chelonia: Emydidae) in marshes from the eastern Iberian Peninsula: first report of Telorchis attenuata (Digenea: Telorchiidae)
}

\author{
Jesús Cardells, María Magdalena Garijo*, Clara Marín, Santiago Vega \\ Universidad Cardenal Herrera-CEU, Facultad de Veterinaria, Moncada, Valencia, Spain. \\ ${ }^{*}$ Correspondence: Instituto de Ciencias Biomédicas, Universidad Cardenal Herrera-CEU. Phone: +34961369000 ext. 1268, \\ Fax: +34 961369007, E-mail: jcardells@uch.ceu.es
}

Received: 18 September 2012; received in revised form: 15 March 2013; accepted: 29 April 2013.

The present work describes the presence of a digenean in the red-eared turtle Trachemys scripta elegans (WiedNeuwied, 1839) in marshes of the Valencian Community. The faeces and intestinal tract of 105 animals were examined. Only one helminth species was found and identified as the digenean trematode Telorchis atenuatta (Goldberger, 1911), present in the $7.6 \%$ of the animals analysed. This is the first report of the parasite in sliders from Spain. Although conclusions are preliminary due to the limited sampling, our results suggest that the presence of red-eared turtles in new habitats may increase the risk of introducing new microorganisms and new diseases with them, altering the sanitary status of the autochthonous terrapins Mauremys leprosa (Schweigger, 1812) and Emys orbicularis (Linnaeus, 1758).

Key words: helminths; parasites; Telorchis atenuatta; terrapins; Trachemys.

Helmintos del galápago Trachemys scripta elegans (Chelonia: Emydidae) en los marjales de la Comunidad Valenciana: primera cita de Telorchis attenuata (Digenea: Telorchiidae). El presente trabajo describe la presencia de un digénido en la tortuga de Florida Trachemys scripta elegans (Wied-Neuwied, 1839) en los marjales de la Comunidad Valenciana. Se examinaron los tractos intestinales y excrementos de 105 animales. Solamente se encontró una especie de helminto, identificado como el trematodo digénido Telorchis atenuatta (Goldberger, 1911), detectado en el 7,6\% de los animales analizados. Se trata de la primera cita de este parásito en tortugas en España. Aunque las conclusiones son preliminares debido a lo reducido del muestreo, los resultados sugieren que la presencia de galápagos de Florida en hábitats nuevos puede aumentar el riesgo de introducción de microorganismos y enfermedades, alterando el estado sanitario de los galápagos autóctonos Mauremys leprosa (Schweigger, 1812) y Emys orbicularis (Linnaeus, 1758).

Key words: galápagos; helmintos; parásitos; Telorchis atenuatta; Trachemys.

The red-eared slider Trachemys scripta elegans is an invasive species frequently treated as a pet (SAlZBERG, 1995; TELECKY, 2001), that has become patent in the Spanish marshes in the last years (MARCO et al., 2003). Natural reproduction of this species has been repeatedly observed in Europe under Mediterranean climatic conditions. Recent studies alert of the danger associated with invasive species introduction due to the alteration of turtle resident communities through various processes including predation, competitive exclusion or parasites transfer (Arvy \& SERvan 1998; Cadi \& Joly, 2003, 2004). Some authors have also reported weight loss and high mortality in the autochthonous European pond turtle (Emys orbicularis) when coexisting with $T$. scripta 
(CADI \& Joly, 2004; PÉREZ et al., 2006).

In Spain, two native species, the Mediterranean pond turtle (Mauremys leprosa) and E. orbicularis are currently sharing habitat with T. scripta (Pleguezuelos, 2002; Cox et al., 2006). In 2005 the Valencian Community (east of Spain) reported the existence of twelve marshals in which native turtles coexisted with the slider turtle (BATALLER \& FORTEZA, 2005). In 2008 this number decreased to eight, as a consequence of invasive species control programs (BATALLER et al., 2008). Previous studies reported the presence of nematodes of the genera Falcaustra, Serpinema, Physaloptera, Aplectana and trematodes of the genus Patagium in T. scripta and native turtles in Spain (EsCH et al., 1979; Roca et al., 2005; Hidalgo-Vila et al., 2006, 2009; Villarán \& DomíngueZ, 2009; AlarCos et al., 2010).

The goal of this study was to analyse the existence of parasites in wild exotic turtles in Valencian Community's marshes. As a result of the survey we describe for the first time the presence of a digenean trematode Telorchis attenuata in wild red-eared slider populations from Spain.

Between July and October 2008, a total of 105 specimens of the subspecies T. scripta elegans from three marshes in the Valencian Community were examined: 32 from Peñíscola, 25 from Almenara and 48 from La Safor. In all those places T. scripta elegans is sharing territory with autochthonous species. Animals were captured with netting and floating traps and were carried in individual boxes to a necropsy room at the University CEUCardenal Herrera. Of the total number of animals examined, 73 were females and 32 males. Weight was recorded and grouped into three categories. Forty-eight animals weighted less than $500 \mathrm{~g} ; 33$ between 500 and $1000 \mathrm{~g}$, and the other (24) exceeded $1000 \mathrm{~g}$. Individual faecal samples were collected and observed under a stereo microscope to assess for the presence of adult nematodes. Moreover, faeces were processed by a standard flotation concentration method, and the concentrate obtained was observed under the microscope in order to detect helminth eggs. Red-eared sliders were sacrificed by a sodium thiopental injection (Dolethal ${ }^{\circ}$, Vétoquinol, Lure, France) and digestive tracts were removed, opened and content diluted in Ringer's solution and observed under the stereo microscope. The recovered helminths were counted and preserved in formaldehyde $10 \%$ being fixed under pressure between two slides during 24 hours. Then, trematodes were stained with hematoxylin and mounted in lactophenol for posterior identification (HidALGO-VILA et al., 2009).

From all individuals examined, only eight turtles were parasitized, all of them infected with adult trematodes (prevalence: $7.6 \%$ ). The only identified species was Telorchis atenuatta (Goldberger, 1911) (Fig. 1). The mean intensity of parasitism was 11.3 helminths per host (min-max, 1-33). The parasitic burden found in the positive animals is shown in Table 1.

After processing faeces, no adults were found under the stereomicroscope; however, all the positive animals at the necropsy were simultaneously excreting eggs in faeces, which were observed by concentration. No other nematodes, cestodes or acantocephalans were observed in the coprological analysis or in necropsies.

All the positive turtles came from a single locality (Almenara), except one turtle coming from La Safor. From the infected turtles, six were determined as females and two as males. 


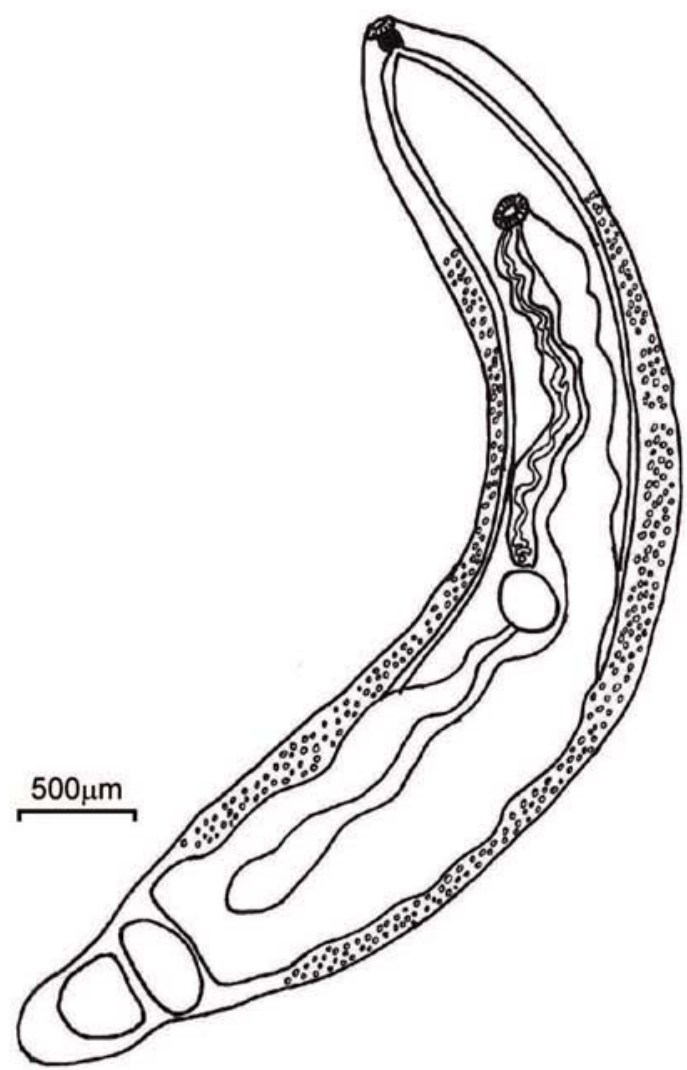

Figure 1: Adult specimen of Telorchis attenuata (Goldberg, 1911).

Regarding weight, three weighted less than $500 \mathrm{~g}$, three between 500 and $1000 \mathrm{~g}$, and the remaining two weighted more than $1000 \mathrm{~g}$.

Previous studies carried out in Spain showed the presence of nematodes, trematodes and cestodes in the autochthonous turtles M. leprosa and E. orbicularis (LÓPEZ-NEYRA, 1947; LÓPEZ-ROMÁN, 1974; LluCH et al., 1987; Cordero del CAMPILlo et al., 1994; KIRIN, 2001; RocA et al., 2005; HidALGOVila et al., 2006; VilLarán \& DOMÍNGUEZ, 2009; AlarCOS et al., 2010). Regarding the invasive species T. scripta, a study in southwest Spain reported four nematode genera, but no trematodes (Hidalgo-VILA et al., 2009). Our study, however, shows exclusively the presence of trematodes. This lack of congruence between studies might be due to the fact that in many cases exotic traded turtles come from eggs originated in farms, and thus have not been previously in contact with natural habitats (WARWICK et al., 2001; HIDALGOVILA et al., 2009).

Esch \& GibBOns (1967) found an increment in parasitism intensity of nematodes and trematodes in turtles during the first four years of life, progressively decreasing between the five and ten years. Authors suggest that this variation might be related to changes in diet and sexual maturity. The basis for this generalization rests in the knowledge that in many turtle species, juveniles are obligate carnivores while adults are primarily herbivores (MOLL \& LEGLER, 1971; PARMENTER \& AVERY, 1990; ESCH et al., 1993; DERSLICK 1999). In our study, the fact that all but one of the parasitized animals were captured in the same area might suggest a stronger relation to dietary habits than to age or sex. According to other authors, T. scripta can accidentally ingest intermediate hosts of trematodes, like snails, when feeding on vegetables (EsCH et al., 1979; KENNEDY et al., 1986).

Table 1: Sex, weight (in grams) and number of trematodes (Intensity) detected on the T. scripta elegans specimens included in this study.

\begin{tabular}{cccc}
\hline \hline Individual & Sex & Weight $(\mathrm{g})$ & Intensity \\
\hline 1 & Female & 1200 & 1 \\
2 & Male & 700 & 12 \\
3 & Female & 500 & 1 \\
4 & Male & 350 & 11 \\
5 & Female & 800 & 18 \\
6 & Female & 650 & 6 \\
7 & Female & 300 & 33 \\
8 & Female & 1800 & 8 \\
\hline
\end{tabular}


The trematode Telorchis has been previously described in different parts of the world parasitizing water turtles. In Mexico, T. attenuata was found in the intestine of T. scripta (MORAVEC \& Vargas-Vásquez, 1998; Pérez-Ponce et al., 2001); in Tunisia, T. temimi was identified in E. orbicularis (MISHRA \& GONZÁLEZ, 1978), and in the same host three species of the genus (T. assula, T. parvus and T. stossichi) were detected in Austria (HASSL \& KLEEWEIN, 2010). In Spain, the species T. solivagus was found in M. leprosa (LÓPEZ-Román, 1974, LLUCH et al., 1987). However, the species identified in this study, T. attenuata, was not previously cited in Spain, although it was in the original distribution range of the host species (Moravec \& VArgas-VÁsquez, 1998). One possibility could be that $T$. scripta elegans individuals were already parasitized when they reached the marshes and that they could survive thanks to the presence of adequate intermediate hosts. Another possibility could be that Trachemys was not sampled previously in this region. The life cycle of Telorchis is not well known, but assuming a typical digenean cycle, the first intermediate host could be a freshwater snail and the second one, where the infective metacercaria develops, a hemipteral larvae (CHENG, 1978). The main snail genera acting as intermediate hosts in Telorchis infecting reptiles (T. corti) are Lymnaea spp., Planorbis spp. and Physella spp. (BARRAGÁn-SÁEnZ et al., 2009). All of them have been previously described in Spain. However, it seems that for Telorchis spp., survival depends on other resources rather than on intermediate hosts' availability (RADTKE et al., 2002).

The introduction of T. scripta in new habitats may be accompanied with the arrival of new microorganisms and diseases (DASZAK et al., 2001, Polo-CaVia et al., 2010). In order to assess this possibility, it would be necessary to extend the study to autochthonous turtles living in syntopy. Considering the presence of trematodes in autochthonous turtles in other areas from Spain, like the ones detected in $M$. leprosa from Castilla y León (Alarcos et al., 2010), or the species Patagium pellucidum in the same host from Extremadura (RocA et al., 2005), we do not discard the possibility that they might also be present in the study area.

\section{Acknowledgement}

Conselleria de Medi Ambient, Aigua, Habitatge i Urbanisme funded the project. Jose María Gil helped during sampling.

\section{REFERENCES}

Alarcos, G.; Casanova, J.C.; Flechoso del Cueto, F. \& Lizana M. (2010). Parásitos en heces de galápagos autóctonos (Emys orbicularis y Mauremys leprosa) en Castilla y León, España, In XI Congreso Luso-Español de Herpetología / XV Congreso Español de Herpetología. Anfibios y Reptiles ante el Cambio Global. Facultad de Biología, Universidad de Sevilla, Sevilla, Spain, p. 225. Arvy, C. \& Servan, J. (1998). Imminet competition between Trachemys scripta and Emys orbicularis in France. Mertensiella 10: 33-40.

Barragán-Sáenz, F.A.; SÁnchez-NaVA, P.; Hernández-Gallegos, O. \& SalgadoMaldonado, G. (2009). Larval stages of trematodes in gasteropods from Lake Chicnahuapan, state of Mexico. Parasitology Research 105: 1163-1167. 
Bataller, J.V. \& FortezA, A. (2005). Mejora del Hábitat de las Poblaciones de Galápago Europeo (Emys orbicularis) en la Comunidad Valenciana. Memoria de Actuaciones (2003-2005). Generalitat Valenciana, Conselleria de Territori i Habitatge, Valencia, Spain.

Bataller, J.V.; BARTOlOMÉ, M.A.; Pradillo A.; Sarzo, B.; Vilalta, M.; Cervera, F. \& Monsalve, M.A. (2008). Control de Poblaciones de Galápagos Exóticos en Humedales de la Comunidad Valenciana. Informe de Actividades del Equipo Técnico de Seguimiento de Fauna Amenazada. Generalitat Valenciana, Conselleria de Medi Ambient, Aigua, Urbanisme i Habitatge, Valencia, Spain.

CADI, A. \& JolY, P. (2003). Competition for basking places between the endangered European pond turtle (Emys orbicularis galloitalica) and the introduced red-eared slider (Trachemys scripta elegans). Canadian Journal of Zoology 81: 1392-1398.

CADI, A. \& Joly, P. (2004). Impact of introduction of red-eared slider (Trachemys scripta elegans) on survival rates of the European pond turtle. Biodiversity and Conservation 13: 2511-2518.

Cheng, T. (1978). Parasitología General. AC Ed., Madrid, Spain.

Cordero del Campillo, M.; CastañónOrdóñez, L. \& Reguera-FeO, A. (1994). Indice Catálogo de Zooparásitos Ibéricos. $2^{\text {nd }} \mathrm{ed}$. Secretariado de Publicaciones, University of León, León, Spain.

Cox, N.; Chanson, J. \& STUART, S. (2006). The Status and Distribution of Reptiles and Amphibians of the Mediterranean Basin. The World Conservation Union (IUCN), Gland, Switzerland and Cambridge, UK.
Daszak, P.; Cunningham, A.A. \& HyatT, A.D. (2001). Anthropogenic environmental change and the emergence of infectious diseases in wildlife. Acta Tropica 78: 103-116.

DeRSLIK, M.J. (1999). Dietary notes on the red-eared slider (Trachemys scripta) and river cooter (Pseudemys concinna) from Southern Illinois. Transactions of the Illinois State Academy of Science 92: 233-241.

Esch, G.W. \& GibBons, W. (1967). Seasonal incidence of parasitism in the painted turtle, Chrysemys picta marginata (Agassiz, 1857). Journal of Parasitology 53: 818-821.

Esch, G.; Gibbons, W. \& Bourque, J. (1979). The distribution and abundance of enteric helminths in Chrysemys s. scripta from various habitats on the Savannah River Plant in South Carolina. Journal of Parasitology 65: 624-632.

Esch, G.W.; Marcogliese, D.J.; Goater, T.M. \& JACOBSON, C. (1993). Aspects of the evolution and ecology of helminth parasites in turtles: a review. In J.V. Gibbons (ed.) Life History and Ecology of the Slider Turtle. Smithsonian Institution Press, Washington DC, USA, pp. 299-307.

Hassl, A.R. \& KleEWeIn, A. (2010). Identifying parasites as substitution causes in populations of local and allocthonous turtles in Lower Austria, In 32nd Annual Meeting of the Austrian Society for Hygiene, Microbiology and Preventive Medicine (ÖGHMP). Österreichische Gesellschaft für Hygiene, Mikrobiologie und Präventivmedizin, Vienna, Austria.

Hidalgo-Vila, J.; Ribas, A.; Florencio, M.; Pérez-Santigosa, M. \& Casanova, J.C. (2006). Falcaustra donanaensis sp. nov. 
(Nematoda: Kathlaniidae) a parasite of Mauremys leprosa (Testudines, Bataguridae) in Spain. Parasitology Research 99: 410-413. Hidalgo-Vila, J.; Díaz-Paniagua, C.; Ribas, A.; Florencio, M.; PÉreZ-Santigosa, M. \& Casanova, J.C. (2009). Helminth communities of the exotic introduced turtle, Trachemys scripta elegans in southwestern Spain: Transmission from native turtles. Research in Veterinary Sciences 86: 463-465. Kennedy, C.R.; Bush, A.O. \& Aho, J.M. (1986). Patterns in helminth communities: Why are birds and fish different?. Parasitology 93: 205-215.

KIRIN, D.A. (2001). New data on the helminth fauna of Emys orbicularis L (1758) (Reptilia, Eymydidae) in South Bulgaria. Comptes Rendus de l'Académie Bulgare des Sciences 54: 95-98.

Lluch, J.; Roca, V.; Navarro, P. \& MasComa, S. (1987). Helmintofauna de los herpetos ibéricos: estado actual de conocimientos, consideraciones ecológicas y estimaciones coprológicas. In V. Sans-Coma; S. Mas-Coma \& J. Gosálbez (eds.) Mamiferos y Helmintos. Kretes Ed., Barcelona, Spain, pp. 143-161.

López-Neyra, C.R. (1947). Helmintos de los Vertebrados Ibéricos. CSIC, Instituto Nacional de Parasitología de Granada, Granada, Spain.

LÓPEZ-Román, R. (1974). Trematodes de las Tortugas de España, I. Redescripción de Telorchis solivagus Odhner, 1902 (Telorchiidae, Digenea) parásito de Clemmys leprosa Schweigger. Revista Ibérica de Parasitología 34: 185-195.

Marco, A.; Hidalgo-Vila, J.; PÉrezSantigosa, C.; Díaz-Paniagua, C. \& Andreu, A. (2003). Potencial invasor de galápagos exóticos comercializados e impacto sobre ecosistemas mediterráneos. In L. Capdevilla-Argüelles; B. Zilletti \& N. Pérez-Hidalgo (eds.) Contribuciones al Conocimiento de las Especies Exóticas Invasoras. Grupo Especies Invasoras Ed., Serie Técnica 1, León, Spain, pp. 76-78.

MishrA, G.S. \& GonZÁLEZ, J.P. (1978). Parasites of fresh water turtles in Tunisia. Archives de l'Institut Pasteur de Tunis 55: 303-326.

Moll, E.O. \& LEGLER, J.M. (1971). Life history of a neotropical slider turtle, Pseudemys scripta (Schoepff), in Panama. Bulletin of the Los Angeles County Museum of Natural History 11: 101-102.

MoraVEC, F. \& VARGas-VÁsqueZ, J. (1998). Some endohelminths from the freshwater turtle Trachemys scripta from Yucatán, Mexico. Journal of Natural History 32: 455-468.

Parmenter, R.R. \& AverY, H.W. (1990). The feeding ecology of the slider turtle, In J.W. Gibbons (ed.) Life History and Ecology of the Slider Turtle. Smithsonian Institution Press, Washington DC, USA, pp. 257-266.

Pérez, N.; Díaz, C.; Hidalgo-Vila, J.; Marco, A.; Andreu, A. \& Portheault, A. (2006). Características de dos poblaciones reproductoras del galápago de Florida, Trachemys scripta elegans, en el suroeste de España. Revista Española de Herpetología 20: 5-17.

Pérez-Ponce, G.; Jiménez-Ruiz, A.; Mendoza-Garfias, B. \& GarcíaPRIETO, L. (2001). Helminth parasites of garter snakes and mud turtles from several localities of the Mesa Central of Mexico. Comparative Parasitology 68: 9-20.

Pleguezuelos, J.M. (2002). Las especies introducidas de anfibios y reptiles, In J.M. Pleguezuelos; R. Márquez \& M. Lizana 
(eds.). Atlas y Libro Rojo de los Anfibios y Reptiles de España. Dirección General de Conservación de la Naturaleza-Asociación Herpetológica Española, Madrid, Spain, pp. 501-532.

Polo-Cavia, N.; Gonzalo, A.; López, P. \& Martín, J. (2010). Predator recognition of native but not invasive turtle predators by naïve anuran tadpoles. Animal Behaviour 80: 461-466.

RadtKe, A.; McLennan, D.A. \& BRoOKS,

D.R. (2002). Resource tracking in north American Telorchis spp (Digenea: Plaguiorchiformes: Telorchidae). Journal of Parasitology 88: 874-879.

Roca, V.; SÁnCheZ, N. \& MarTín, J.E. (2005). Intestinal helminth parasitizing Mauremys leprosa (Chelonia: Bataguridae) from Extremadura (western Spain). Revista Española de Herpetología 19: 47-55.
Salzberg, A. (1995). Report on import/export turtle trade in the United States, In J.J. Behler; I. Das; B. Fertard; P. Pritchard; B. Branch; L. Durrel \& J. Fretey. (eds.) Proceedings of the International Congress of Chelonian Conservation. Soptom Eds., Gonfaron, France, pp. 314-322.

Telecky, T.M. (2001). United States import and export of live turtles and tortoises. Turtle and Tortoise Newsletter 4: 8-13.

Villarán, A. \& Domínguez, J. (2009). Infestación múltiple de Mauremys leprosa por nematodos. Boletín de la Asociación Herpetológica Española 20: 37-39.

WarWICK, C.; Lambiris, A.J.L.; WestwoOd, D. \& Steedman, C. (2001). Reptile-related salmonelosis. Journal of the Royal Society of Medicine 94: 124-126. 